\title{
U.S. - South America Ocean Grain Freight Spreads
}

\author{
March 2015
}

Jay O’Neil

\section{Senior Agricultural Economist \\ The International Grains Program Institute (IGP) \\ Kansas State University (KSU)}

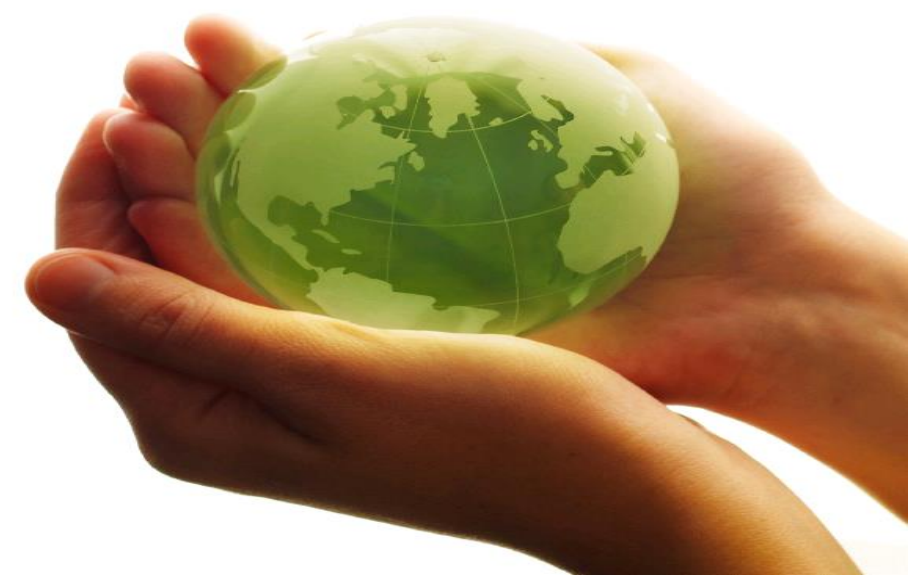

\section{International Grains Program Institute 1980 Kimball Ave, \#102 IGP Bldg. Manhattan, KS 66506}

Author Contact: Jay O’Neil, joneil@ksu.edu, 785-532-2868

USDA Contact: Delmy L. Salin, delmy.salin@ams.usda.gov, 202-720-0833.

Recommended Citation: O'Neil, Jay. U.S. - South America Ocean Grain Freight Spreads. IGP Technical Report. March 2015. Posted at http://hdl.handle.net/2097/18876 and Web <http://dx.doi.org/10.9752/TS212.03-2015>

Acknowledgements: This work was supported by Cooperative Agreement Number 12-25A-5640, with the U.S. Department of Agriculture's (USDA) Agricultural Marketing Service (AMS). 
Disclaimer: The opinions and conclusions expressed do not necessarily represent the views of the U.S. Department of Agriculture or the Agricultural Marketing Service. 


\section{What Is the Issue?}

In recent years, the United States-the world's leading producer and exporter of soybeans-has lost market share to Argentina and Brazil (Salin and Somwaru 2014). At the farm level, the 2013 per-bushel total production costs in the main producing areas of the U.S. Midwest averaged $\$ 9.62$ per bushel, compared with $\$ 7.14$ per bushel in Argentina. Per-acre costs in Brazil demonstrate a similar comparative advantage. The cost is $\$ 8.15$ per bushel in the Brazilian State of Mato Grosso and \$7.68 per bushel in Paraná (Salin and Somwaru 2014). Even though, U.S. production costs are higher, the total transportation costs from point of production to the ultimate destination in Asia are generally lower than for South America, allowing U.S. soybeans to compete. However, relatively small differences in seaborne transportation costs can make South America soybean exports more competitive than those of the United States, diverting trade from the United States to Brazil or Argentina, and/or the other way around (Salin and Somwaru 2014).

To understand transportation costs from the farm to port requires more than quantifying a rail tariff, barge, and ocean contract rates to move a commodity from one point to another. At any given moment there are a wide variety of transportation factors that will impact the transportation costs and therefore the price U.S. farmers receive for their crop. These can include the availability of domestic transportation equipment, floods, high or low water on the River system, port costs and port delays. International ocean freight rates do not include the cost of port delivery or delays caused by the lack of readily available rail equipment at harvest time, fuel surcharge fluctuations, and other domestic issues. Long wait times at a load or discharge port will, however, be reflected in the vessel Charter Party terms and in the demurrage and dispatch rates negotiated.

This study highlights the market influences that affect ocean freight spreads between North and South American ports of origin to Asia and how these spreads affect the

competitiveness of U.S. grain exports to Asia. Rate comparisons from the U.S. Gulf to China have been used as opposed to the U.S. Pacific Northwest (PNW) because of the limitations presented by the Panama Canal and the Canal transit costs as this is where the Atlantic freight spread competition exists.

\section{What Did the Study Find?}

Ocean freight rates for grain cargos from South America to Asia are often less expensive than from the U.S. Gulf because of dry-bulk vessel route patterns, lower-cost port charges, higher Panama Canal tolls, and less burdensome navigation restrictions. South America shipments provide some natural competitive advantages for Brazilian and Argentinean grains and oilseeds by avoiding the Panama Canal when the need exists. As such, South American shippers can often load larger vessels without incurring in Canal fees and delays. Brazilian ports also provide less expensive berthing (dockage) costs for vessels.

Seasonal port backlogs impact the logistical flow of commodities and shipper costs, but in a supply push market these extra costs generally get passed back to the local producers 
rather than the shipper or commodity buyer and therefore have a smaller effect on ocean freight rate spreads.

\section{How Was the Study Conducted?}

There is no readily-available public data identifying the United States and South America ocean freight spreads. This study is based on primary data from O’Neil Commodity Consulting. Secondary data sources are USDA-AMS Transportation Services Division, Bluewater Shipping Port statistics, and the Panama Canal Authority. Some ocean transportation data is derived from reports and database materials from 2012-2014, but which are understood to be accurate through the end of the calendar year 2013. The study does not include inland transportation costs in each competing region.

\section{Methodology:}

This report briefly presents a comprehensive study of the market factors that influence Dry-bulk ocean freight market spreads on grain and oil seed shipments from North and South America to Asia. This study focuses on Handymax and Panamax type Dry-Bulk vessels commonly utilized in the grain industry.

To simplify and better understand the ocean market analysis, the study underscore the impact of distance, trade flows, seasonality, transit times, and port cost in the determination of market spreads/cost differences between North and South American origins to Asia. Seasonal port backlogs also impact shipper costs and the logistical flow of commodities. However, these extra costs often get passed back to the local producers rather than the shipper or commodity buyer, resulting in a smaller effect on ocean freight rate spreads. This study presents a cost comparative analysis of shipments from the U.S. Gulf/Mississippi River and Pacific Northwest (PNW) grain ports with current ports of Brazil and Argentina. For this report, when the term "grain" is used it refers to corn, wheat, soybeans and sorghum. The term "tonnes" in this report will represent metric tons (mt), 1,000 kilograms or 2,204.6 pounds. Moreover, the cost comparison does not include inland transportation costs for each competing region. 


\section{U.S. and South America Ocean Freight Transportation}

When discussing the world of ocean freight, freight rates, and freight rate spreads, there are many dynamics at play in the shipment of goods by sea. First, there are different vessels of varying sizes and types that carry different cargo on numerous routes around the world. Not all commodities can be moved in all ship types and not all ports can accommodate vessels of all sizes. As new vessels are put into service and older vessels are scrapped, freight rates will follow the general economic principals of vessel supply verses cargo demand. Second, vessels tend to move in specific freight lanes until market economics change and encourage them to move to a new region and route.

Grain, fertilizer, coal, and other commodities primarily move around the world in what are called dry bulk vessels. Dry-bulk is a term used to describe ocean going vessels that have 4-9 cargo holds (table 1) into which coal, ore, metals, fertilizer, and grains can be directly poured into and easily discharged in bulk. These vessels are configured differently than general cargo (tween deck vessels), tanker, liquid bulk, and container ships. The world dry-bulk fleet is comprised of various cargo size vessels (tables 1). The larger ships, from Suezmax and up, are not typically used to carry grains and oil seeds.

Table 1. Vessel Sizes

\begin{tabular}{|l|c|c|l|}
\hline \multicolumn{1}{|c|}{ Vessel Catogory } & $\begin{array}{c}\text { Cargo Size } \\
\text { tonnes }\end{array}$ & $\begin{array}{c}\text { Number } \\
\text { of Holds }\end{array}$ & \multicolumn{1}{|c|}{ Comments } \\
\hline Handysize & $20,000-29,000$ & 4 & \\
Handysize (new) & $25,000-38,000$ & 5 & \\
Handymax & $38,000-49,000$ & 5 & \\
Supramax & $50,000-60,000$ & 5 & \\
Ultramax & $60,000-65,000$ & 5 & \\
Panamax & $59,000-76,000$ & 7 & Not often used for grain \\
Kamsarmax & $76,000-85,000$ & 7 & Not often used for grain \\
Post-Panamax & $85,000-95,000$ & 7 & Not often used for grain \\
\hline Suezmax & $75,000-100,000$ & 8 & Not used for grain \\
Baby Cape & $100,000-118,000$ & 9 & Not used for grain \\
\hline Capesize & $145,000-190,000$ & 9 & 9 \\
\hline Very Large Bulk Carrier & $200,000-349,000$ & 9 & \\
\hline Ultra Large Bulk Carrier & $350,000-545,000$ & & \\
\hline
\end{tabular}

${ }^{1}$ Tonnes in this report will represent metric tons (mt).

Source: O’Neil Commodity Consulting

Iron ore, coal, and steel products comprise about 40 percent of all dry-bulk cargo on the seas. Grains and oil seeds comprise between 10 -14 percent of global dry-bulk trade. For reasons of economic efficiency, iron ore, coal, and steel products generally ship in the larger vessels, Capesize and above. When these larger vessels are in short supply the market will reach down into the Panamax, Ultramax and Supramax markets for added 
supply. The coal trade often utilizes Panamax vessels and competes with grains for the service of these vessels. Panamax are the mid-sized cargo ships that are capable of passing through the lock chambers of the original Panama Canal which are 1,050 ft. (320.04 m) in length, $110 \mathrm{ft}$. (33.53 m) in width, and $41.2 \mathrm{ft}$. (12.56 m) in depth. The new expanded Panama Canal is scheduled to be completed by April 2016 and will provide for the passage of larger vessels.

Conversely, when Handymax through Panamax size vessels are in short supply for grain and oilseed movements there is very limited opportunity to enlist the services of the larger Baby-Cape and Capesize vessels (table 1). This is because many grain and oilseed loading ports, and most grain receiving ports, do not have the berth length over all (LOA) or salt water arrival draft (SWAD) to accept the larger vessels. It should be noted that vessels have more buoyancy in salt water then in fresh water and that this will cause some restrictions as to where they can load or discharge.

The cost of product relative to a buyer's credit limits and cash flow can also be a limiting issue for buyers when considering the purchase of a larger single shipment. Larger cargo quantities have higher individual invoice amounts.

In today's grain and oilseed markets, the larger shipments of 60-68,000 $\mathrm{mt}$ tend to originate in Brazil and move to China (table 2). This is because many shipments from Brazil do not have to transit through the Panama Canal and therefore can be loaded to deeper depths.

Due to draft limitations at most U.S. west coast ports and the current restrictions of moving through the Panama Canal on shipments from the U.S. Gulf, most grain shipments from the U.S. to Asia normally contain 45-58,000 mt of cargo. This will change for grain shipments as newer, more efficient, vessels are delivered and once the new expanded Panama Canal project is completed in April of 2016. These changes will allow ships to load to deeper drafts with cargoes of up to 68-80,000 mt of grain depending on the configuration of the vessel.

We are already seeing bigger cargoes loaded out of Mississippi River and other ports as more of the new style Kamsarmax and Post-Panamax vessels are delivered into the fleet. These vessels are able to lift larger quantities of grain on relatively lighter drafts. But these bigger vessels can only ship to customers who can accommodate bigger cargoes and ships.

Many world grain buyers, such as Japan, Central and South American and S.E. Asian customers have receiving ports with arrival drafts of just 11.9 meters or less. This restriction will not allow them to receive bigger cargoes than they currently purchase. 
Table 2. Vessel Shipments from Selected Origins to Selected Destinations

\begin{tabular}{|c|c|c|}
\hline Destination & Origin & Cargo Size (Metric tons) \\
\hline \multirow[t]{4}{*}{ China } & U.S. Gulf & $30-70,000$ \\
\hline & U.S. PNW & $50-64,000$ \\
\hline & Argentina & $50-56,000$ \\
\hline & Brazil & $55-69,000$ \\
\hline \multirow[t]{4}{*}{ Korea } & U.S. Gulf & $50-56,000$ \\
\hline & U.S. PNW & $31-66,000$ \\
\hline & Argentina & $50-58,000$ \\
\hline & Brazil & $50-60,000$ \\
\hline \multirow[t]{4}{*}{ Taiwan } & U.S. Gulf & $50-56,000$ \\
\hline & U.S. PNW & $45-55,000$ \\
\hline & Argentina & $45-56,000$ \\
\hline & Brazil & $55-60,000$ \\
\hline \multirow[t]{4}{*}{ Japan } & U.S. Gulf & $23-52,000$ \\
\hline & U.S. PNW & $27-64,000$ \\
\hline & Argentina & $40-48,000$ \\
\hline & Brazil & $40-50,000$ \\
\hline \multirow[t]{4}{*}{ Indonesia } & U.S. Gulf & $54-56,000$ \\
\hline & U.S. PNW & $49-67,000$ \\
\hline & Argentina & $55-60,000$ \\
\hline & Brazil & $54-60,000$ \\
\hline \multirow[t]{4}{*}{ Mexico } & U.S. Gulf & $25-45,000$ \\
\hline & U.S. PNW & $25-45,000$ \\
\hline & Argentina & $25-45,000$ \\
\hline & Brazil & $25-45,000$ \\
\hline \multirow[t]{4}{*}{ Colombia } & U.S. Gulf & $20-45,000$ \\
\hline & U.S. PNW & $35-45,000$ \\
\hline & Argentina & $35-45,000$ \\
\hline & Brazil & $35-45,000$ \\
\hline \multirow[t]{4}{*}{ Egypt } & U.S. Gulf & $50-74,000$ \\
\hline & U.S. PNW & $50-60,000$ \\
\hline & Argentina & $50-60,000$ \\
\hline & Brazil & $50-69,000$ \\
\hline Netherlands & U.S. Gulf & $70-76,000$ \\
\hline
\end{tabular}

Source: O'Neil Commodity Consulting 


\section{Recommended U.S. Gulf and Pacific Northwest Deep Transit Drafts}

\section{U.S. Gulf - Mississippi River:}

There is industry concern regarding how consistent the U.S. Army Corps of Engineers (Corps) will be at maintaining adequate depths and widths for the Southwest Pass, the navigation channel that connects the Mississippi River with the Gulf of Mexico. The Corps is authorized to maintain the channel depth to 45 feet and the width to 750 feet. The current draft is 47 feet as the Corps is able to dredge an additional 2 feet at the same cost while maintaining the 45 foot minimum requirement. The Mississippi River, however, carries large amounts of sediment and is in constant need of dredging at the mouth of the river in order to allow fully laden ${ }^{1}$ vessels in or out. Currently, most loaded grain vessels transiting the Southwest Pass are in the 43 foot draft range.

Table 3. Maximum Vessel Drafts at U.S. Ports

\begin{tabular}{|c|c|c|c|}
\hline \multicolumn{4}{|c|}{ U.S. Gulf and Pacific Northwest Drafts } \\
\hline Port -Berth & Draft (feet) & Draft (meters) & Comments \\
\hline \multicolumn{4}{|c|}{ U.S. Gulf-Mississippi River Ports } \\
\hline Southwest Pass to Pilot Town & 47 & 14.326 & \multirow{4}{*}{$\begin{array}{l}\text { River is not always dredged and } \\
\text { maintained at this level }\end{array}$} \\
\hline Pilot Town to New Orleans & 47 & 14.326 & \\
\hline New Orleans to Mile 180 AHP* & 47 & 14.326 & \\
\hline Mile 180 AHP to Baton Rouge & 45 & 13.716 & \\
\hline \multicolumn{4}{|c|}{ U.S. Pacific Northwest } \\
\hline EGT, Longview, WA & 43 & 13.1 & Located on the Comumbia River \\
\hline Kalama Export Co, Kalama, WA & 43 & 13.1 & Located on the Comumbia River \\
\hline Temco, LLC Kalama, WA & 43 & 13.1 & Located on the Comumbia River \\
\hline United Grain Corp, Vancouver, WA & 43 & 13.1 & Located on the Comumbia River \\
\hline Columbia Grain, Portland, OR & 43 & 13.1 & Located on the Comumbia River \\
\hline Temco, LLC Portland, OR & 40 & 12.19 & Located on the Willamette River \\
\hline LD Commodities LLC, Portland, OR & 40 & 12.19 & Located on the Willamette River \\
\hline \multicolumn{4}{|c|}{ Puget Sound, WA } \\
\hline AGP Grays Harbor T-2 & 40 & 12.19 & Located on the Puget Sound Inlet \\
\hline LD C-Seattle & 73 & 22.3 & Located on the Puget Sound Inlet \\
\hline Temco - Tacoma & 70 & 21.3 & Located on the Puget Sound Inlet \\
\hline
\end{tabular}

*AHP refers to "Above Head of Pass", or mile zero at the entrance to the Southwest Pass lading into the Mississippi River.

Source: O’Neil Commodity Consulting

\footnotetext{
${ }^{1}$ Loaded vessel
} 


\section{PNW Ports:}

As the above chart indicates, the much deeper drafts in the Puget Sound allow those west coast facilities to load larger cargoes verses the facilities in the Columbia River. Current PNW grain elevator draft restrictions are subject to tidal/river conditions, pilot confirmation, and elevator agreement. The maximum permissible deep transit draft for the Columbia River in the PNW is 43 feet Fresh Water (13.1 meters FWAD (Fresh Water Arrival Draft)).

\section{Cost of Fuel and Vessel Fuel Consumption}

Dry-Bulk vessel maximum speed is 16-19 knots and the average voyage speed today is closer to 11-12 knots (table 4). To cut costs during times of poor shipping profitability, vessel operators will employ a tactic called slow steaming to save on fuel expenses. The practice of slow steaming can reduce a vessels speed to 9.5-11 knots. This saves on fuel expenses but adds considerably to voyage transit times between ports.

Table 4. Vessel Speeds

\begin{tabular}{|l|c|c|}
\hline Vessel Type & Max. Speed in knots & $\begin{array}{c}\text { Average Speed in } \\
\text { knots }\end{array}$ \\
\hline Container & $22-24$ & $14-15$ \\
RoRo & $20-20$ & $13-14$ \\
Dry-Bulk & $16-19$ & $11-12$ \\
\hline
\end{tabular}

Source: O'Neil Commodity Consulting

\section{U.S. Gulf and Pacific Northwest Port Charges}

The cost of berthing a vessel at a particular port has considerable influence on the competitiveness of that port as these costs are directly reflected in the ocean freight rate charged by the vessel operator. The cost of fuel and the cost of berthing vary from port to port and berth to berth. These cost differences are exhibited below in the Tables 5, 6, 7, and 8.

Grain elevators dockage fees account for 50 to 60 percent of the total port charges (tables 5 and 7). Please note that all ten Mississippi River Grain Elevators assess dockage for selftrimming bulk carrier vessel using the flat rate dockage system whereby a lump sum amount is charged based on vessels' gross registered ton (GRT). The lump sum amount applies regardless of the time the vessel is alongside the berth for loading. Vessels loading out of the Ports of Brownsville, TX, Mobile, AL, Brunswick, GA, and Norfolk, VA, can capture the savings related to lower dockage fees at these ports. The ports of Brownsville, TX, Mobile, AL, and Brunswick, GA, however, are restricted on vessel and cargo size due to shallower drafts. These ports will normally load Handy and Handymax size vessels. The port at Norfolk, VA, has the capability of loading Panamax ships. 
Table 5. Mississippi River Grain Vessel Disbursement Fees

\begin{tabular}{|c|c|c|}
\hline Vessel Disbursements $^{1}$ & Handymax & Panamax \\
\hline $\mathrm{SDW}^{2} / \mathrm{GRT}^{3} / \mathrm{NRT}^{4}$ & $55,000 / 30 / 18$ & $75,000 / 40 / 26$ \\
\hline \multicolumn{3}{|l|}{ Mississippi River } \\
\hline Government & $\$ 2,000.00$ & $\$ 2,500.00$ \\
\hline Pilotage & $\$ 40,000.00$ & $\$ 50,000.00$ \\
\hline Towage 2 in $\& 2$ out & $\$ 23,000.00$ & $\$ 25,000.00$ \\
\hline Lineman & $\$ 2,475.00$ & $\$ 2,475.00$ \\
\hline Launch official & $\$ 7,500.00$ & $\$ 7,500.00$ \\
\hline N.C. $B^{5} /$ USDA Inspection & $\$ 4,500.00$ & $\$ 5,200.00$ \\
\hline $\begin{array}{l}\text { Dockage (Basis lumpsum rate } \\
\$ 3.32 \text { per GRT) }\end{array}$ & $\$ 99,600.00$ & $\$ 132,800.00$ \\
\hline Dock Clean-Up & $\$ 425.00$ & $\$ 425.00$ \\
\hline Dust Arrest Tarps & $\$ 400.00$ & $\$ 400.00$ \\
\hline Security & $\$ 2,000.00$ & $\$ 2,000.00$ \\
\hline Harbor Fees & $\$ 1,200.00$ & $\$ 1,200.00$ \\
\hline Vessel Agency Fees & $\$ 4,300.00$ & $\$ 4,500.00$ \\
\hline Agency Expenses & $\$ 2,575.00$ & $\$ 2,575.00$ \\
\hline Est. Owner Expenses & $\$ 2,500.00$ & $\$ 2,500.00$ \\
\hline Gross TOTAL & $\$ 192,475.00$ & $\$ 239,075.00$ \\
\hline Per mt & $\$ 3.50$ & $\$ 3.42$ \\
\hline \multicolumn{3}{|l|}{${ }^{1}$ As of August 2014} \\
\hline \multicolumn{3}{|l|}{${ }^{2}$ SWD- Summer Deadweight } \\
\hline \multicolumn{3}{|c|}{${ }^{4}$ NRT- Net Rated Tonnage of a vessel } \\
\hline \multicolumn{3}{|c|}{${ }^{5}$ N.C.B.-National Cargo Bureau } \\
\hline
\end{tabular}

Source: Bluewater Shipping

All ten Mississippi River Grain Elevators assess dockage for self-trimming Bulk Carrier (STBC) using the flat rate dockage system whereby a lump sum amount is charged based on vessels GRT (table 6). The lump sum amount applies regardless of the time vessel is alongside the berth for loading. 
Table 6. Mississippi River Current Dockage rates for Self-Trimming Bulk Carrier (STBC) (effective August 2014)

\begin{tabular}{|l|c|l|}
\hline \multirow{2}{*}{ Mississippi River Elevators } & \multirow{2}{*}{ River Mile Point } & Dockage Rate \\
\cline { 3 - 3 } & & $\begin{array}{l}\text { Per Gross Rated } \\
\text { Ton (GRT) }\end{array}$ \\
\hline ADM Grain Elevator Ama & 117.6 & $\$ 3.32$ \\
\hline ADM Grain Elevator Destrehan & 120.6 & $\$ 3.32$ \\
ADM Grain Elevator Reserve & 139.1 & $\$ 3.32$ \\
\hline ADM Grain Elevator St. Elmo & 150.5 & $\$ 3.32$ \\
Bunge Destrehan & 120.5 & $\$ 3.29$ \\
Cargill, Inc. Westwego & 103.5 & $\$ 3.25$ \\
\hline Cargill, Inc. Reserve & 139.6 & $\$ 3.25$ \\
Cenex Harvest States & 61.5 & $\$ 3.32$ \\
LDC Port Allen & 229.2 & $\$ 3.12$ \\
Zen-noh Grain Elevator Convent & 163.8 & $\$ 3.30$ \\
\hline
\end{tabular}

Source: O'Neil Commodity Consulting 
Table 7. U.S. Pacific Northwest Grain Loading Disbursement

\begin{tabular}{|c|c|c|}
\hline Vessel Disbursements $^{1}$ & Handymax & Panamax \\
\hline $\mathrm{SDW}^{2} / \mathrm{GRT}^{3} / \mathrm{NRT}^{4}$ & $55,000 / 30 / 18$ & $75,000 / 40 / 26$ \\
\hline \multicolumn{3}{|l|}{ U.S. Pacific Northwest } \\
\hline Harbor Dues & $\$ 880.00$ & $\$ 880.00$ \\
\hline Oil Spill contingency fee & $\$ 545.00$ & $\$ 545.00$ \\
\hline Bar Pilot shifting in \& out & $\$ 8,900.00$ & $\$ 10,200.00$ \\
\hline River Pilot shifting in \& out & $\$ 14,500.00$ & $\$ 16,200.00$ \\
\hline Tug Assist in \& out & $\$ 23,000.00$ & $\$ 24,000.00$ \\
\hline Lineman & $\$ 4,400.00$ & $\$ 4,400.00$ \\
\hline Launch hire & $\$ 2,100.00$ & $\$ 2,100.00$ \\
\hline Dockage & $\$ 106,850.00$ & $\$ 128,700.00$ \\
\hline Security $(\$ 1,100.00 /$ day $)$ & $\$ 3,300.00$ & $\$ 3,300.00$ \\
\hline N.C.B ${ }^{5}$ / USDA Inspection & $\$ 4,100.00$ & $\$ 4,600.00$ \\
\hline U.S. Customs & $\$ 3,800.00$ & $\$ 1,900.00$ \\
\hline Vessel Agency Fees & $\$ 4,300.00$ & $\$ 4,500.00$ \\
\hline Agency Expenses & $\$ 2,575.00$ & $\$ 2,575.00$ \\
\hline Gross TOTAL & $\$ 179,250.00$ & $\$ 203,900.00$ \\
\hline Per mt & $\$ 3.26$ & $\$ 2.91$ \\
\hline \multicolumn{3}{|l|}{${ }^{1}$ As of August 2014} \\
\hline \multicolumn{3}{|l|}{${ }^{2}$ SWD- Summer Deadweight } \\
\hline \multicolumn{3}{|l|}{${ }^{3}$ GRT- Gross Registered Ton } \\
\hline \multicolumn{3}{|c|}{${ }^{4}$ NRT- Net Rated Tonnage of a vessel } \\
\hline \multicolumn{3}{|c|}{${ }^{5}$ N.C.B.-National Cargo Bureau } \\
\hline
\end{tabular}

Source: Bluewater Shipping 
Table 8. Pacific Northwest Current Dockage rates for Self-Trimming Bulk Carrier (effective August 2014)

\begin{tabular}{|c|c|c|c|c|}
\hline $\begin{array}{l}\text { U.S. West Coast Ports } \\
\text { Elevators }\end{array}$ & $\begin{array}{l}\text { Mile } \\
\text { Point }\end{array}$ & \begin{tabular}{|c|} 
Dockage Rate \\
Per Gross \\
Rated Ton \\
(GRT)
\end{tabular} & Effective date & Comments \\
\hline \multicolumn{5}{|c|}{ Columbia River } \\
\hline EGT,LLC & 66 & $\$ 3.30$ & February 1,2014 & $\begin{array}{l}\text { Minimum dockage charge on any ocean going vessel is } \$ 30,000 \text {. Tanker or Tween } \\
\text { Decker vessels will be assessed an additional charge of } \$ 2.75 \text { per GRT for each } 24 \text { hour } \\
\text { period, or fraction thereof } \$ 1.00 \text { per GRT for each additional } 24 \mathrm{hr} \text {, or part thereof, }\end{array}$ \\
\hline Kalama ExportCo. & 74 & $\$ 3.30$ & January 1,2014 & $\begin{array}{l}\text { For the first } 48 \text { hours of each berthing event, time starting at first line. After } 48 \text { hours } \\
\text { of each berthing event, an additional } \$ 1.00 \text { per GRT for each } 24 \text { hour period, or } \\
\text { fraction thereof, will be assessed until the vessel vacates the berth (last line). }\end{array}$ \\
\hline $\begin{array}{c}\text { TEMCO, LLC, Kalama } \\
\text { Terminal }\end{array}$ & 77 & $\$ 3.30$ & May 15,2013 & Dockage $\$ 3.30$ per GRT for first 3 days. $\$ 0.85$ per GRT for each 24 hour period thereafter. \\
\hline $\begin{array}{l}\text { Columbia Grain Terminal } \\
5\end{array}$ & 102 & $\$ 2.95$ & October 1,2014 & $\begin{array}{l}\text { Dockage Charges for the 1st 72-hrs (3 days) as follows: Vessels GRT up to and } \\
\text { including 25,000: \$3.40 per GRT. Vessels GRT over 25,000 up to and including 35,000: } \\
\text { \$3.30 per GRT. Vessels GRT over 35,000: \$2.95 per GRT. Each additional period of } 24 \\
\text { consecutive hours: \$0.95 per GRT. }\end{array}$ \\
\hline United Grain Corporation & 104 & $\$ 3.30$ & July 1,2014 & $\begin{array}{l}\text { Vessels loading less then 25,000 } \mathrm{mt} \$ 1.00 / \text { GRT per } 24 \text { hour period. Vessels loading } \\
\text { over 25,000 mt } \$ 3.30 / \text { GRT for the first } 72 \text { hours. After } 72 \text { hours } \$ 1.00 / \text { GRT for each } \\
\text { additional } 24 \text { hour period. }\end{array}$ \\
\hline $\begin{array}{c}\text { TEMCO, LLC Portland } \\
\text { Terminal } \\
\end{array}$ & 108 & $\$ 3.30$ & May 15, 2013 & Dockage $\$ 3.30$ per GRT for first 3 days. $\$ 0.85$ per GRT for each 24 hour period thereaft \\
\hline $\begin{array}{l}\text { LD Commodities NW } \\
\text { Facility, LLC }\end{array}$ & 109 & $\$ 2.27$ & February 1,2012 & \begin{tabular}{|l} 
Dockage charges for the 1st 72-hrs (3 days) as follows: \\
- Vessels GRT up to and including 25,000: \$2.65 per GRT; \\
- Vessels GRT over 25,001 up to and including 35,000: \$2.43 per GRT \\
- Vessels GRT over 35,000: \$2.27 per GRT \\
- Fourth 24-hour period: \$0.92 per GRT \\
- Fifth 24-hour period: \$0.97 per GRT \\
- Sixth and subsequent 24-hour periods: \$1.03 per GRT
\end{tabular} \\
\hline \multicolumn{5}{|r|}{ Puget Sound } \\
\hline $\begin{array}{c}\text { LD Commodities Seattle } \\
\text { Export Elevator, LLC }\end{array}$ & 103 & $\$ 3.20$ & \multirow[b]{2}{*}{ June 1,2011 } & \\
\hline TEMC0, LLC - Tacoma & 136 & $\$ 3.55$ & & $\begin{array}{l}\text { Dockage \$3.30 per GRT for first } 3 \text { days. \$0.85 per GRT for each } 24 \text { hour period } \\
\text { thereafter. Dockage } \$ 3.55 \text { per GRT for vessels with lifting gear. } \$ 0.85 \text { per GRT for each } \\
24 \text { hour period thereafter. }\end{array}$ \\
\hline \multicolumn{5}{|c|}{ Grays Harbor District } \\
\hline AGP-Terminal-2 & & $\$ 1.70$ & April 1,2013 & $\$ 0.60$ per GRT for each additional 24-hour period \\
\hline
\end{tabular}

Source: O'Neil Commodity Consulting 


\section{The United States verses South America Ocean Freight Spreads}

The market spread, or cost difference, for vessels moving Dry-bulk cargo from North America verses South America to Asia is predicated on various market factors including daily hire rates, vessel ballasting patterns, and fuel and port costs. To determine a specific freight rate and establish a prevailing freight spread a vessel owner/operator would make a voyage calculation based on all of the above mentioned factors. However, prevailing market conditions at any time may dictate that vessel freight trade above or below these straight cost calculations. Table 9, 10, and 11 shows a simple example of how vessel cost per $\mathrm{mt}$ is calculated. It should be noted that the ocean cost per $\mathrm{mt}$ shown on these tables are an accurate assessment of vessel freight costs at a given point in time. However, this is not the final cost per mt paid because the prevailing market conditions at any time may dictate that vessel freight trade above or below these straight cost calculations. Consequently, the market will trade at whatever price level it deems appropriate.

Ocean freight rates for grain cargos from South America to Asia are often less expensive than from the U.S. Gulf because of dry-bulk vessel route patterns, lower-cost port charges, Panama Canal tolls, and navigation restrictions (tables 9, 10, and 11). South America locations provide some natural competitive advantages for Brazilian and Argentinean shipments by avoiding the Panama Canal when the need exists. As such South American shippers can often load larger vessels without incurring Canal fees and delays. One of the biggest differences in costing noted from above is the "total port and canal fees (table 9). The fees for the U. S. Gulf route to Shanghai are estimated at $\$ 550,000$; from Argentina are $\$ 430,000$; and from Brazil \$180,000 (table 9).

Seasonal port backlogs impact the logistical flow of commodities and shipper costs but in a supply push market (markets where supply is abundant) these extra costing generally get passed back to the local producers rather than the shipper or commodity buyer and therefore have a smaller effect on ocean freight rate spreads. This is true whether commodities are sold free on board ${ }^{2}$ (FOB) or cost and freight ${ }^{3}$ (CNF).

Loading delays and vessel backups in South America are often much longer than in the United States. But these costs are for the account of the charterer and not the vessel so they do not tend to greatly influence the per $\mathrm{mt}$ freight rate. The cost of the resulting vessel demurrage does however have a significant impact on the value of the Free on Board (FOB) cargo and the price received by South American producers. For example, "FOB Santos" shows that the Brazilian seller will pay for transporting the grain to the Port of Santos and

\footnotetext{
${ }^{2}$ FOB is an acronym for free on board. FOB Origin indicates that the sale is considered complete at the seller's shipping dock, and thus the entity buying the goods is responsible for freight costs/liability.

${ }^{3}$ CNF stands for Cost and Freight. The term refers to a common type of shipping agreement where the seller pays for delivering the item to the port closest to the buyer. CNF shipping terms does not include the cost of cargo insurance. The buyer must pay for insuring the item from the point of origin to the final destination unless the terms of sale are CIF (Cost Insurance and Freight). The buyer also must pay various other fees, such as customs fees and any storage fees at the destination port.
} 
the cost of loading the grain on to the ship, including inland haulage, customs clearance, origin documentation charges, and demurrage. Once all the grain is on board, the buyer pays for all costs beyond that point.

Table 9. Vessel costs from U.S. Gulf verses Argentina and Brazil to Shanghai, China

\begin{tabular}{|l|c|c|c|}
\hline \multirow{2}{*}{ Cargo Mean Quantity =/- 10\% } & U.S. Gulf & Argentina & Brazil \\
\cline { 2 - 4 } & $\mathbf{5 6 , 0 0 0} \mathbf{~ m t}$ & $\mathbf{6 0 , 0 0 0} \mathbf{~ m t}$ & $\mathbf{6 6 , 0 0 0} \mathbf{~ m t}$ \\
\hline & & & \\
Nautical miles $(\mathrm{nm})$ & 9,977 & 1,186 & 11,031 \\
Voyage days & 39 & 42.5 & 42 \\
Panama Canal & 1 & & \\
Laytime both ends & 20 & 24 & 23 \\
Total Voyage Duration Days & 60 & 66.5 & 65 \\
& & & \\
APS ${ }^{1}$ Rate $(\$ 20,000 \times 60)$ & $\$ 1,200,000$ & & \\
APS Rate $(\$ 19,000 \times 66.5)$ & & $\$ 1,263,500$ & \\
APS Rate $(\$ 19,000 \times 65)$ & & & $\$ 1,235,000$ \\
Ballast Bonus & $\$ 1,000,000$ & $\$ 900,000$ & $\$ 900,000$ \\
\cline { 2 - 4 } Total Earnings & $\$ 2,200,000$ & $\$ 2,163,500$ & $\$ 2,135,000$ \\
Bunkers & $\$ 650,000$ & $\$ 710,000$ & $\$ 700,000$ \\
\hline Port \& Canal Fees & $\$ 550,000$ & $\$ 430,000$ & $\$ 180,000$ \\
\multicolumn{1}{|c|}{ Percentage of total costs } & 16.2 & 13.0 & 6.0 \\
\hline Total costs & $\$ 3,400,000$ & $\$ 3,303,500$ & $\$ 3,015,000$ \\
\hline Freight Rate: & $\$ \mathbf{5 6 . 6 7}$ & $\mathbf{3 5 5 . 0 6}$ & $\mathbf{3 4 5 . 6 8}$ \\
\hline
\end{tabular}

${ }^{1}$ APS: Arrival Pilot Station

Note: 60,000 dwt vessel. Cargo size: 56,000 (10\% m/l)

Source: O'Neil Commodity Consulting 
Table 10. Summary Cost Estimate of Freight rates from Bahia Blanca, Argentina-Cape Horne-China Route, August 2014

\begin{tabular}{|l|l|}
\hline \multicolumn{1}{|c|}{ Items } & \multicolumn{1}{c|}{ Amount } \\
\hline Distance: & Bahina Blanca to Shanghai 11,186 nm - 42.5 days navigation \\
Number of days: & Bahia Blanca + Shanghai - 24.0 days laytime \\
Round trip duration: & 66.5 days \\
\hline Current arrival pilot station (aps) & $\$ 1.263$ million \\
rate - US $\$ 19,000 x$ 66.5: & $\$ 900,000$ \\
\hline Current ballast bonus: & $\$ 2,163$ \\
Total earnigns: & $\$ 710,000$ \\
Bunkers: & $\$ 430,000$ \\
Port costs: & $\$ 3,303$ \\
\hline Total voyage cost: & Intake 66,000 $\mathrm{mt}$ \\
\hline Cargo 60,000/10 percent more or & $\mathbf{5 0 . 0 4}$ per $\mathbf{~ t t}$ \\
\hline less at vessels option: & Freight
\end{tabular}

Source: O'Neil Commodity Consulting

Table 11. Summary Cost Estimate of Freight rates from New Orleans-Panama Canal-China Route, August 2014

\begin{tabular}{|c|c|}
\hline Items & Amount \\
\hline Distance: & $\begin{array}{l}\text { New Orleans to Shanghai } 9,977 \mathrm{~nm} \text { - } 40 \text { days navigation (incl } \\
\text { extra day for panama) }\end{array}$ \\
\hline $\begin{array}{l}\text { Number of days: } \\
\text { Round trip duration: }\end{array}$ & $\begin{array}{l}\text { U.S. Gulf to Shanghai - } 20 \text { days laytime ( } 18.5 \text { days) } \\
60 \text { days }\end{array}$ \\
\hline $\begin{array}{l}\text { Current arrival pilot station (aps) } \\
\text { rate - US } \$ 20,000 \times 60 \text { : }\end{array}$ & US $\$ 1.200$ million \\
\hline $\begin{array}{l}\text { Current ballast bonus: } \\
\text { Total earnigns: } \\
\text { Bunkers: } \\
\text { Port costs: } \\
\end{array}$ & $\begin{array}{c}\$ 1.000 \text { million } \\
\$ 2.200 \text { million } \\
\$ 650,000 \\
\$ 550,000 \\
\end{array}$ \\
\hline Total voyage cost: & $\$ 3,400$ \\
\hline $\begin{array}{l}\text { Cargo } 56,000 / 10 \text { percent more or } \\
\text { less at vessels option: }\end{array}$ & Intake $60,000 \mathrm{mt}$ \\
\hline Freight & $\$ 56.66$ per mt \\
\hline
\end{tabular}

Source: O'Neil Commodity Consulting 
The maps in Figures 1, 2, 3, 4, and 5 depict different estimated freight rates than those shown in Tables 9, 10, and 11 because they portray a different destination port in China and, for comparison sake, a different freight market period during the year. It should be noted that shipments from Brazil and Argentina do not always follow the same routes to China. Transit times will vary depending on vessel speed.

\section{From East Coast South America to China:}

Figure 1. Port of Santos, Brazil-Good Hope-China route

\section{Santos, Brazil to Guangzhou, China 10,830 nautical miles - 41 days at 11 knots}

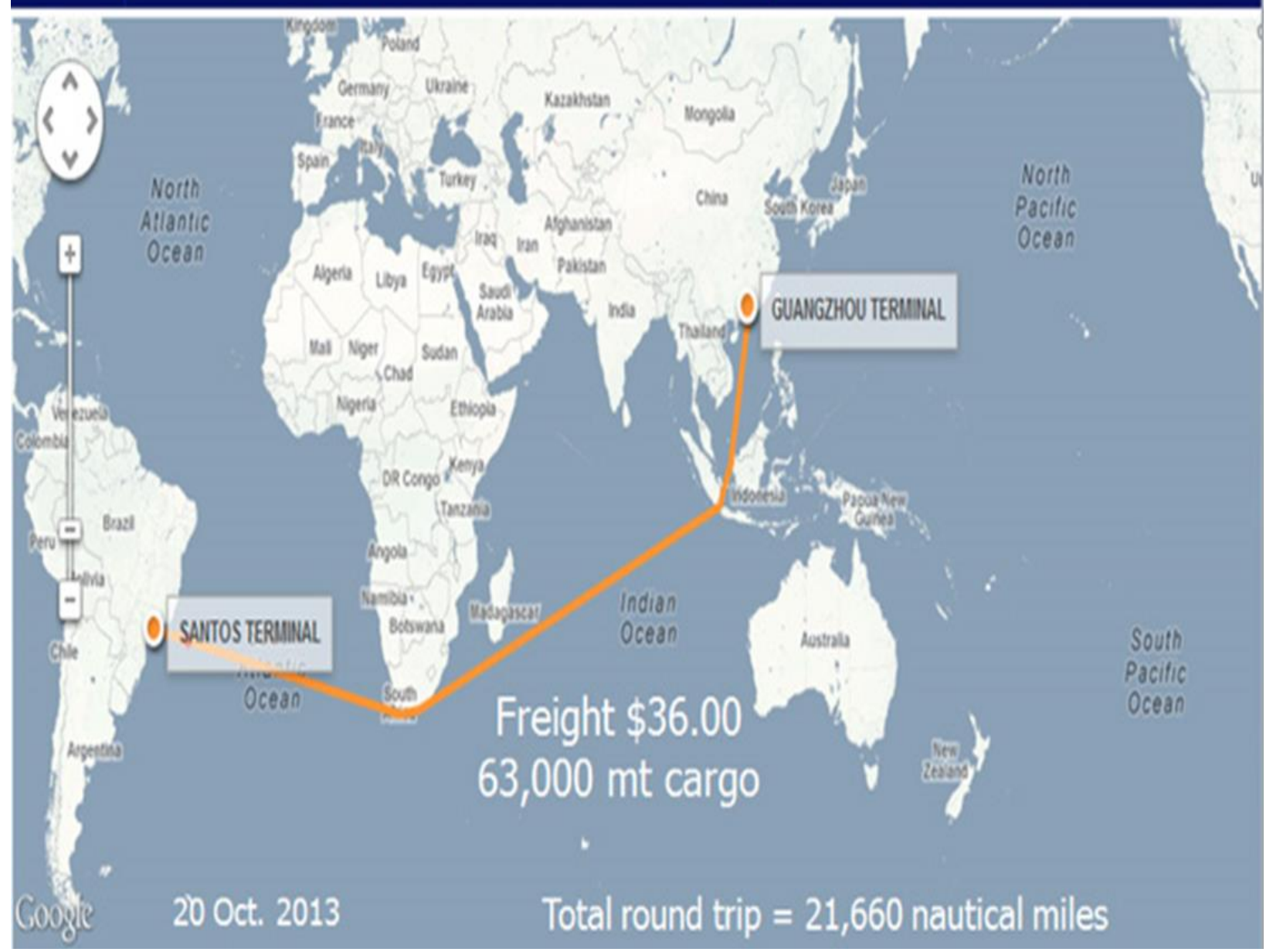

Source: O’Neil Commodity Consulting, (per vesseldistance.com) 


\section{From Argentina to China:}

Figure 2. Port of Bahia Blanca, Argentina-Cape Horn-China route Bahia Blanca, Argentina to Guangzhou, China
11,104 nautical miles- 42 days at 11 knots

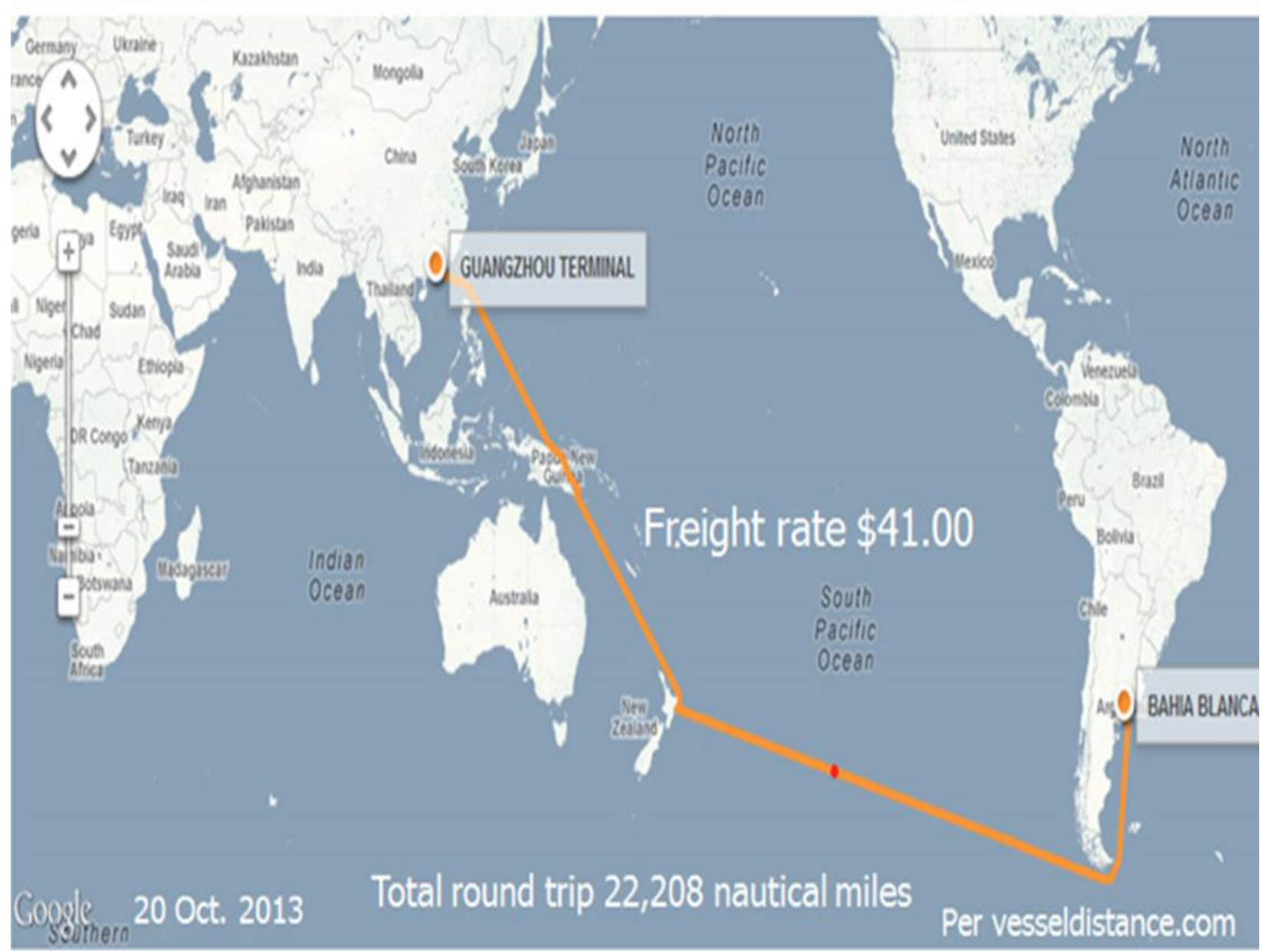

Source: O’Neil Commodity Consulting 


\section{From U.S. Gulf to China:}

Figure 3. Port of New Orleans-Panama Canal-China route

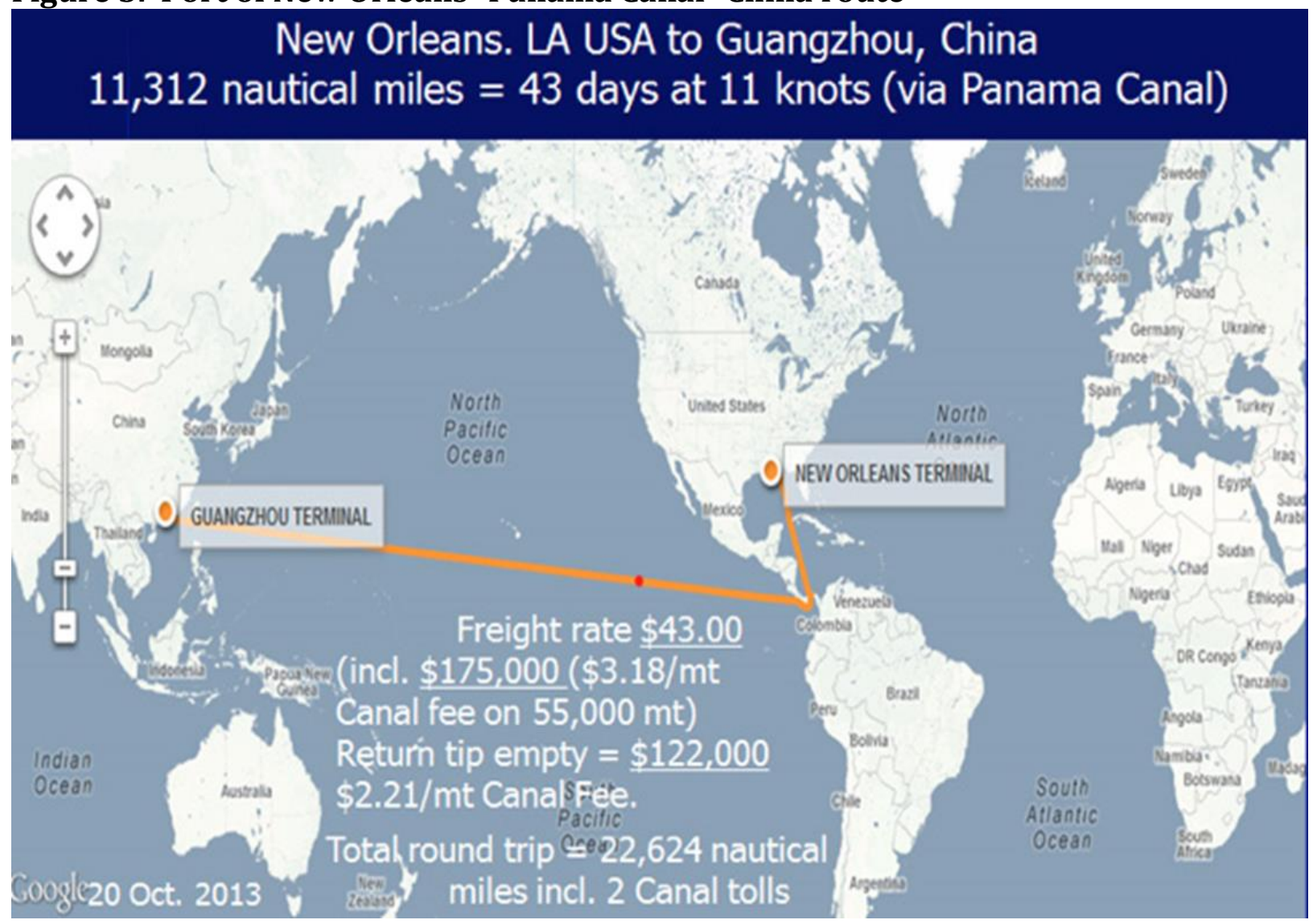

Source: O'Neil Commodity Consulting 
From U.S. Pacific Northwest to China:

Figure 4. Port of Portland to China route

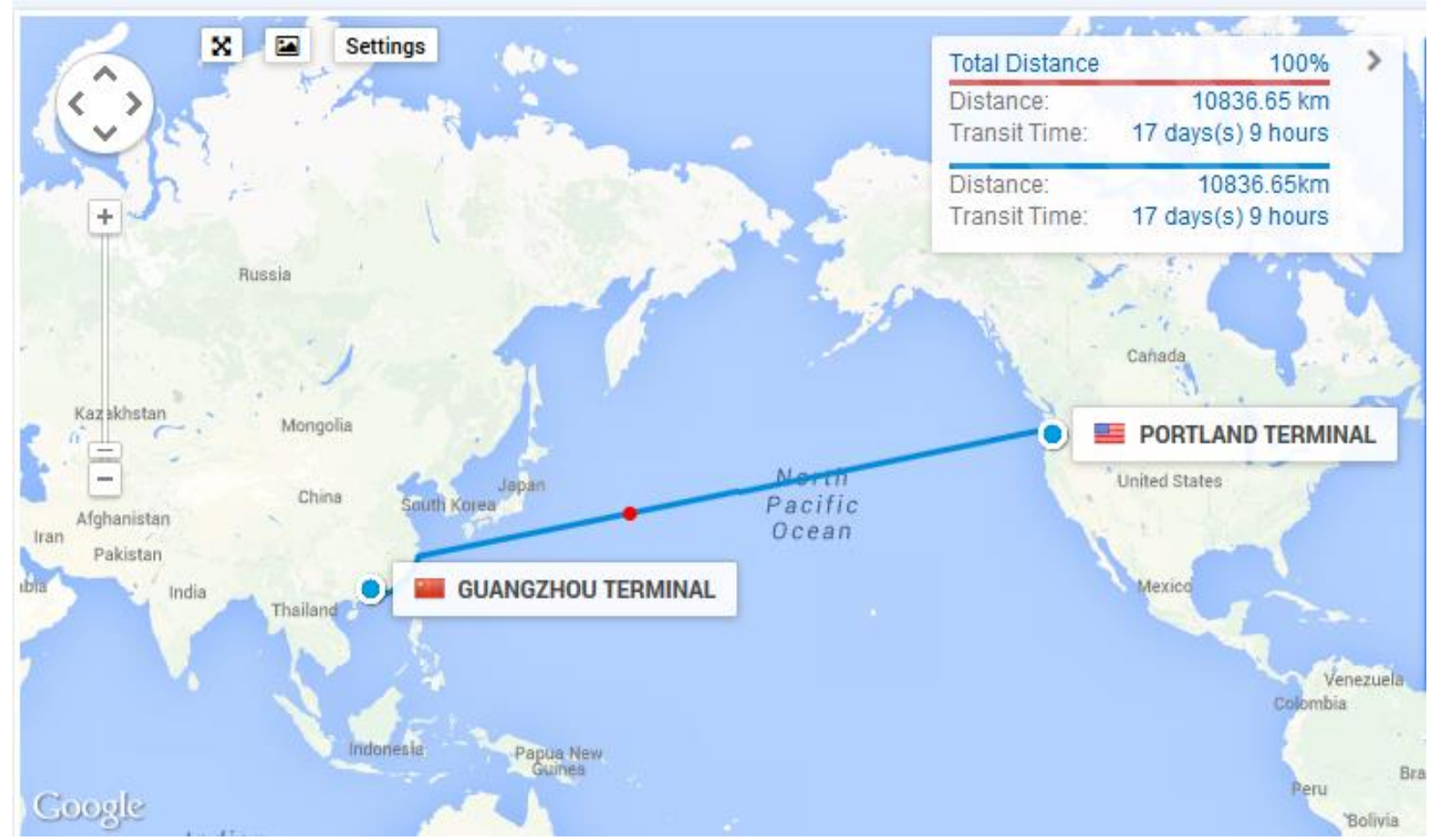

Source: O'Neil Commodity Consulting 


\section{From U.S. Gulf (via Panama Canal) to China vs. Santos, Brazil to China:}

Figure 5. Port of New Orleans-Panama Canal-China and Santos to China routes

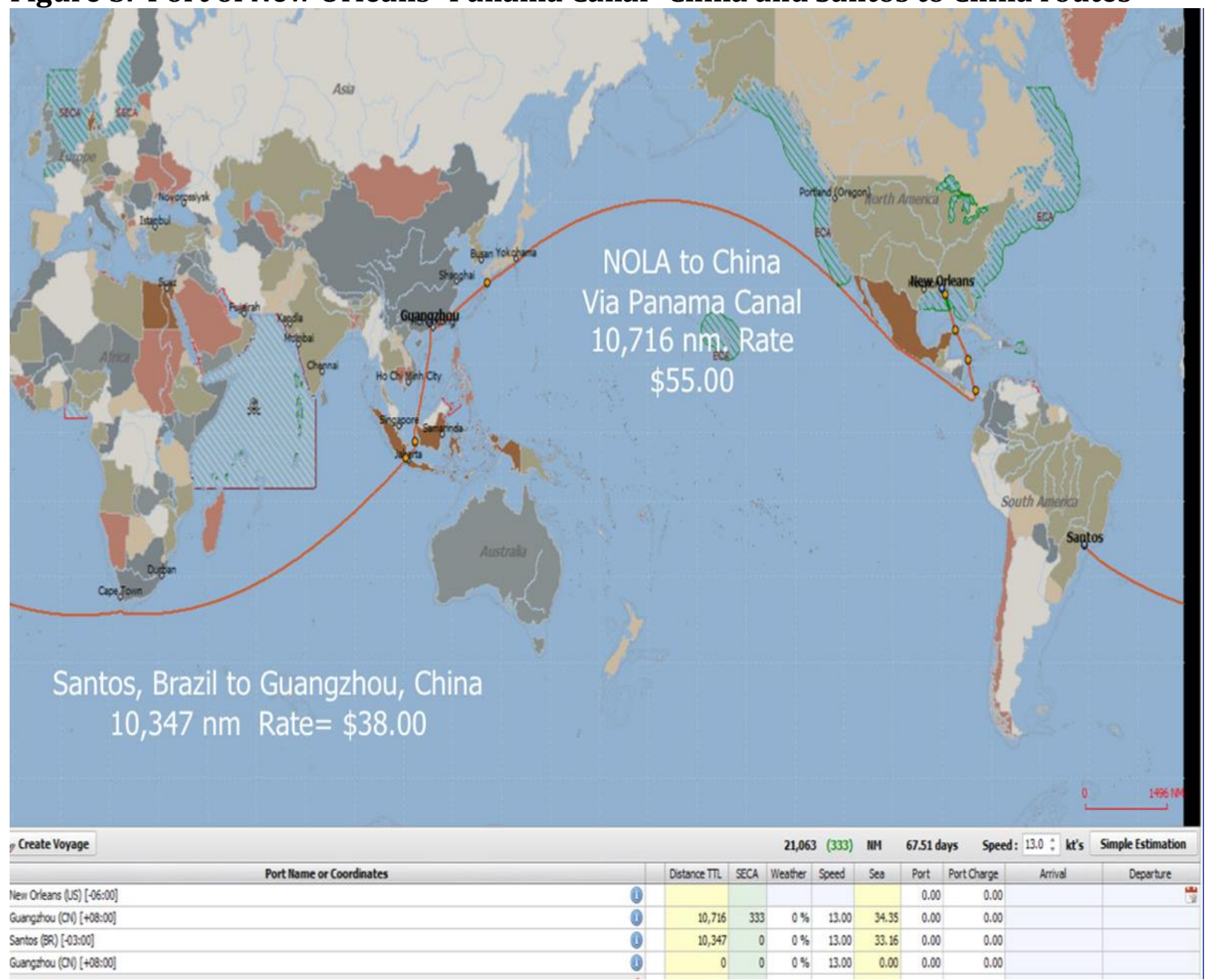

Source: O'Neil Commodity Consulting

Note: The nautical mile distance between ports will vary slightly depending on the data source and seasonal routing.

\section{The New Panama Canal}

There is considerable discussion regarding how the new expanded Panama Canal will affect world ocean freight costs and patterns. The one known is that it will allow for speedier transits and bigger cargoes. For some grain markets this means the ability to load up to 10-15,000 additional tonnes.

The Canal expansion will have the biggest impact on world container shipping markets and in iron ore movements from South American to Asia. The impact on grain movements will not be as large as for these other markets. 
The significant unknowns about the new canal and its competitive posture revolve around the new Canal transit fees and shipper reactions to them. The transit fees have not yet been published but will have an important impact on how vessel routes evolve. If the new canal fees are viewed as too expensive, it will encourage container shipping companies and other industries to consider using the Suez Canal as an alternative route. Additionally, the new Super E Class container vessels of 17-18,000 TEU capacity are already too big to fit through the new expanded Panama Canal (figure 6). This may create the need to shuttle the big container vessels from Asia to the west coast of the Canal to unload onto smaller vessels that can transit. This will be a market dynamic that evolves over time.

\section{Figure 6. The new Panama Canal locks}

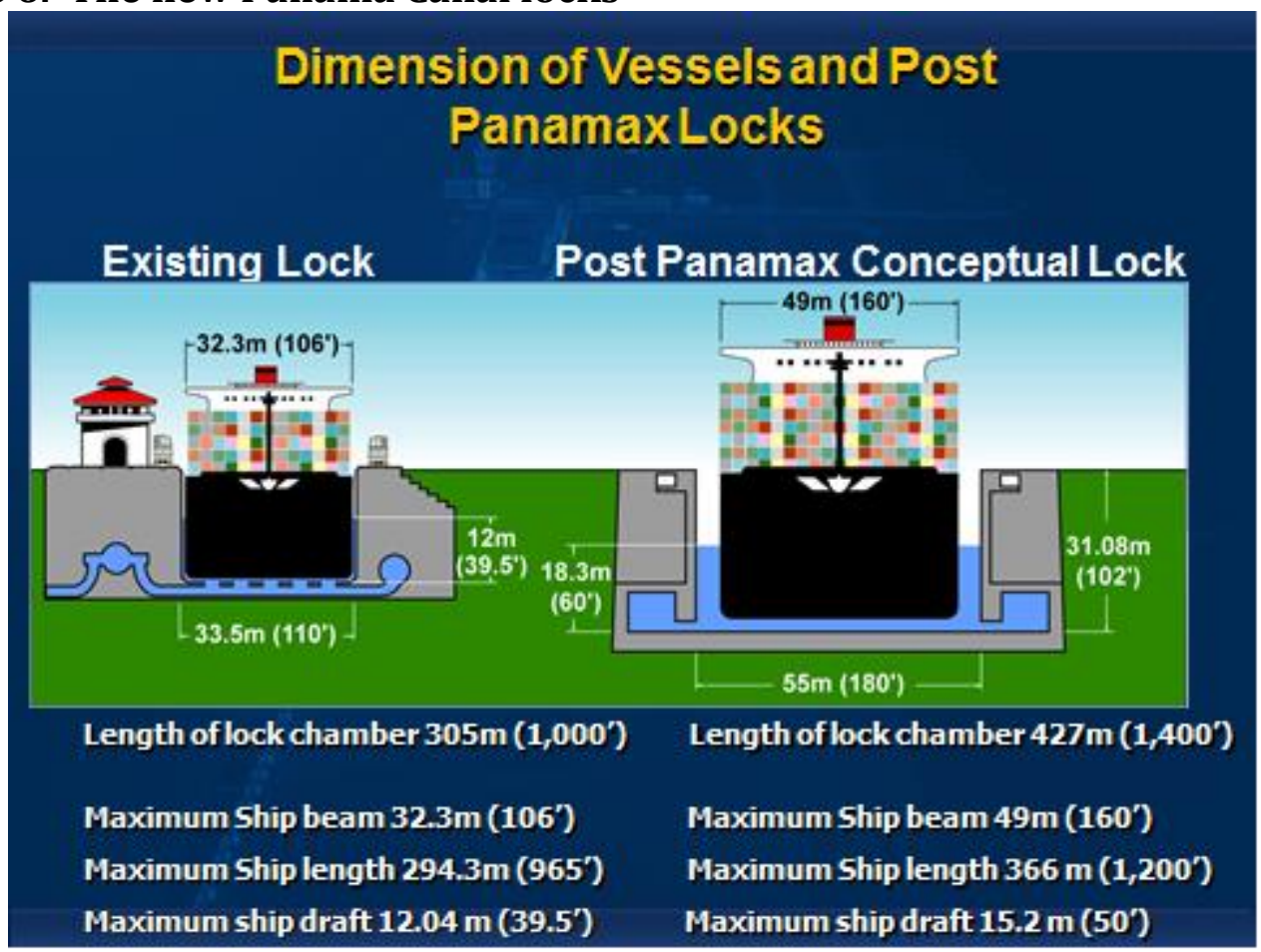

Source: Panama Canal Authority

\section{Conclusion}

The market spread, or cost difference, for vessels moving Dry-bulk cargo from North America verses South America to Asia is dependent on a variety of market factors. These include daily hire rates in each region (Pacific, Atlantic and other areas of the world), vessel ballasting patterns, fuel cost, canal fees, and port costs. The voyage distance for shipments from the U.S. Gulf verses South American grain ports to Asia are not substantially different. If prevailing bunker fuel cost are relatively the same from either origin, this leaves only a few deciding factors to explain the difference in freight costs. 
The most significant variables affecting the market spreads, and therefore the competitiveness, of U.S. Gulf verses South American ports are the current Panama Canal draft restrictions and fees and the difference in port and berth fees. It is therefore often the case that Dry-Bulk ocean freight rates for South American grain moving to Asia are below those of the U.S. Gulf. The spreads between the two port regions can run from even money to as much as a $\$ 15.00$ per $\mathrm{mt}$, or more, difference in favor of South American ports. Theses spreads change seasonally and with prevailing market conditions. 


\section{References}

Blue Water Shipping. 2013. Port Information. <http://www.bluewatershipping.com/> . Accessed 2012 to September 2014.

Dictionary of Terms used in the International Commerce of grain and Oilseeds by Albert Slabotzky - Continental Gain.

Panama Canal Authority (CPA). Personal Communication. September 9, 2014

Salin, Delmy L. and Agapi Somwaru. Eroding U.S. Soybean Competitiveness and Market Shares: What Is the Road Ahead?. U.S. Dept. of Agriculture, Agricultural Marketing Service, September 2014. Web. <http://dx.doi.org/10.9752/147.09-2014

Dictionary of Terms used in the International Commerce of grain and Oilseeds by Albert Slabotzky - Continental Gain.

\section{Glossary}

AHP - Refers to At Head of Passes. Mile 0, is generally referred to as 0 AHP. The pilot town marks the beginning of the river system. Terminals, anchorages, bridges and other specific locations on the river are always given in AHP terms.

Affreightment - A contract of affreightment provides that a vessel owner shall carry goods by sea, or give physical control of a vessel to charterers, in consideration for which charterers pay owners a monetary fee. To charter (hire) a vessel for the carriage of cargo.

APS - means Arrival Pilot Station. It refers to the time/position where the charterer starts paying hire.

Brackish - A mixture of fresh and salt water.

Bulk Carrier - An ocean-going single deck dry cargo vessel.

Bulk Cargo - Cargo shipped loose, not shipped in packages or containers, but shipped loose in the hold of a ship. Grain, coal, and sulfur are usually bulk cargo.

Bunkers - The fuel on which vessels run. The name is derived from the fuel storage space on a vessel (i.e. low grade thick crude) commonly referred to as bunker fuel.

Capesize Vessel - A cargo vessel with a capacity of 110,000-400,000 dwt.

Demurrage - The charge levied when a shipment is not loaded or unloaded within the allowed time. 
Disbursements - Monies paid out.

Dockage - The fee charged for use of a dock or Warf. This should not to be confused with the similar quality term used for wheat.

DWC - Dead Weight Capacity refers to a vessel's lifting or cargo loading capacity in tonnes when loaded in salt water to her summer freeboard marks. Dead weight capacity includes cargo, fuel and crews provisions.

Discharge Rate - The rate per day that a cargo is unloaded from a vessel.

Dockage - Fees charged to a vessel for using a dock.

Draft - The depth of water which a vessel requires in order to float freely.

GRT - Gross Registered Tonnage refers to the tonnage of a vessel as registered, before deduction of light air spaces, machinery and navigating spaces and other parts of the vessel to arrive at the net registered tonnage. The net tonnage of a vessel is about two thirds of her gross tonnage. A ship's total volume expressed in "register tons," which equals a volume of 100 cubic feet $(2.83 \mathrm{~m})$.

Hold - The name for the space below deck on a vessel that is used to store cargo.

LOA - Length overall is the term used to describe vessel and Warf lengths.

Handymax Vessel - A cargo vessel with a capacity of 35,000-49,000 dwt.

Handysize Vessel - A bulk cargo vessel with a capacity of 20,000-34,000 dwt.

Panamax Vessel - A cargo vessel with a capacity of 50,000-75,000 dwt.

Post-Panamax - A cargo vessel with a capacity of 80,000-110,000 dwt.

Nautical mile - A measurement of distance at sea, which is used mainly for speed. One knot is one nautical mile. A mean nautical mile equals 6,076.91 feet.

Net Registered Tonnage (nrt) - Refers to the volume of cargo the vessel can carry and includes gross tonnage less the volume of spaces that will not hold cargo. This term is sometimes referred to as net rated tonnage of a vessel.

Safe Port - Refers to a port which a vessel can safely enter and always stay afloat to load or discharge cargo. 
Self-Trimming Vessel - A vessel arranged structurally for loose dry-bulk cargo flow into holds so that little, if any trimming is required to ensure the cargo completely fills the holds, and does not endanger the vessel's safety by shifting.

SWAD- Refers to Salt Water Arrival Draft.

Ton - Refers to a U.S. short ton.

Tonne - Refers to a metric ton.

Towage - The fee charged to two a vessel into port or berth.

Tween Deck vessel - This term refers to a general cargo vessel with multiple decks (e.g. a deck or decks below the upper deck and above the lowest deck.).

RoRo - Refers to a Roll on and Roll off type of vessel; mostly used to carry automobiles, construction machinery, and any cargo than can be rolled on and off the ship easily. Cargo is not loaded or unloaded over the ships rails but via a ramp door.

STBC - Refers to a Self-Trimming Bulk Carrier, which is a Dry bulk vessel that does not require special trimming of bulk cargo after loading.

ST - A short ton equals 2,000 pounds, and is used in the United States.

MT - A metric ton equals 2,204.6 pounds, and is used internationally.

LT - A long ton equals 2,240.00 pounds, and is common terminology used in vessel freight markets.

TEU - Refers to a twenty foot container equivalent, which is a measurement of container vessel carrying capacity.

Warfage - A charge for use of a Warf for the purpose of loading, discharging or docking a vessel. 